\title{
Study the biological activities of Tribulus terrestris extracts
}

$$
\text { دراسة الفعالية الحيوية لمستخلصات نبات الحسج (أو القطب) }
$$

\author{
Abbas A. Mohammed \\ Ahmed AbdulAmier Hussain Al-Amiery \\ Heba. H. I. Al-Mosowy \\ Amir H. Abbas \\ Biochemical division/Department of applied science/University of Technology
}

$$
\text { عباس عبد الله الجنابي }
$$

\section{Abstract:}

J $n$ this study the extracts of the Iraqi herb Tribulus terrestris (Al-Hassage or AlKutub) was done by using of polar and non polar solvents, then the biological activity of these extractants was studied in two field. First, the antibacterial activity in vitro on gram positive bacteria (Staphylococcus aureus), and gram negative bacteria (E. coli, Proteus vulgaris, Pseudomonas aerugiuosa, and Klebsiella pneumonia), all extracts showed considerable activity against all bacteria. Second, the effect of extracts on free serum testosterone level in male mice in vivo, the alcoholic, and acetonitrilic extracts showed significant $(P<0.05)$ increase in free serum testosterone level, and we found that the extracts contained compounds with less genotoxic effects in mice germ cells.

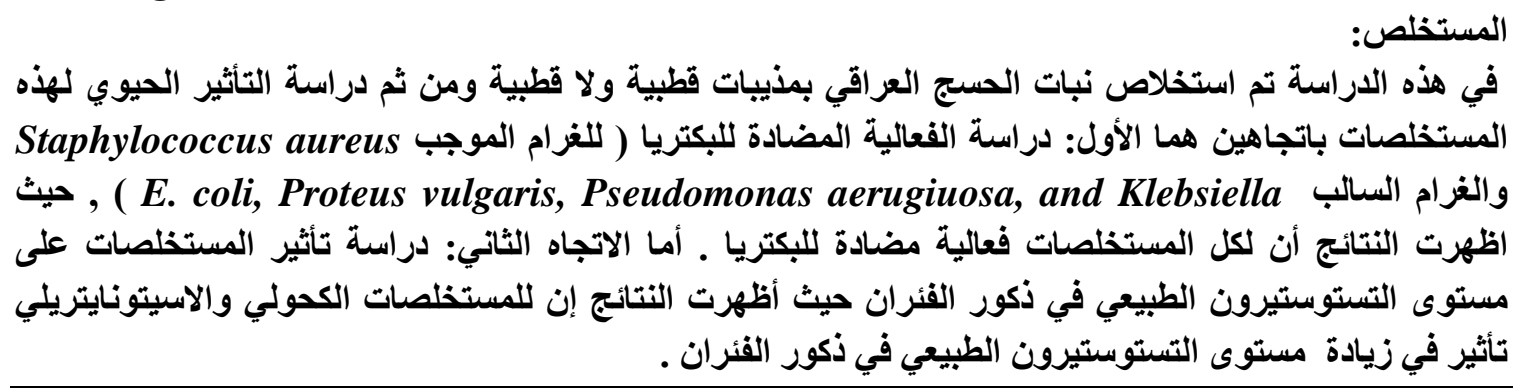

\section{Introduction:}

Tribulus terrestris is a natural herb used for treating many diseases like hypertension [1]. It is a member of the Zygophyllaceae family, and an annual herb found in many tropical and moderate areas of the world, including the U.S. and Mexico, the Mediterranean region, and throughout Asia [2]. Tribulus terrestris, is also known as Puncture Vine, It contains steroidal saponins, and act as a natural testosterone enhancer. Tribulus terrestris increases testosterone through increasing lutenizing hormone ( $\mathrm{LH})$. There is good confidence that Tribulus terrestris is useful as a sexual enhancement herb [3]. In Iraq T. terrestris is used in folk medicine as tonic, aphrodisiac, analgesic, astringent, stomachic, anti-hypertensive, diuretic, lithon-triptic and urinary anti-infectives [4,5]. Mainstream medicine is increasingly receptive of the use of antimicrobial and other drugs derived from plants, as traditional antibiotics become ineffective and because of the rapid rate of plant species extinction. There is a feeling among natural-products chemists and microbiologists alike 
that the multitude of potentially useful phytochemical structures which could be synthesized chemically is at risk of being lost irretrievably [6].

The aim of this work was to study the biological activity of the Iraqi herb Tribulus terrestris as antibacterial and testosterone enhancer moreover study genotoxic effects in germ cells of mice.

\section{Experimental}

\section{Extraction procedure}

Tribulus terrestris were collected from natural habitats during flowering. Air dried plant sample rinsed with water and dried. After evaporation of the solvent, the residues were powdered $250 \mathrm{~g}$ and extracted with $500 \mathrm{ml}, 70 \%$ ethanol (or methanol, or acetonitril, or hexane) in a soxhlet apparatus and the extracts were evaporated to dryness by a rotary evaporator.

Soxhlet. Tribulus terrestris was extracted in a Soxhlet extractor for 24 hours at a maximum temperature of $65^{\circ} \mathrm{C}$, in the proportion of $25 \mathrm{~g}$ of Tribulus terrestris to $5 \mathrm{~L}$. of $70 \%$ ethanol (or methanol, or acetonitril, or hexane).

\section{Analytical procedures}

Yield of Tribulus terrestrisextracts. All extracts were evaporated to dry and weighed to obtain the yield. The results were given as a percentage of the original weight of crude Tribulus.

Thin Layer Chromatography. The analysis was performed on precoated $(20 \mathrm{~cm}$ length, $20 \mathrm{~cm}$ width, and $0.25 \mathrm{~mm}$ thickness) TLC plates K6F silica gel $60 \mathrm{~A}$ purchased from Whatman, USA. The solutions are concentrated to $2 \mathrm{ml}$., $10 \mu$ litter of this solution is applied on the TLC plate, to establish the $\mathrm{R}_{\mathrm{f}}$ value. Detection of the spots was done by the use of spraying Vanillin sulphuric acid reagent.

\section{Agar diffusion assay}

Different strains of bacteria were used which are: Escherichia coli, Pseudomonas aeruginosa, Klebsiella, Proteus vulgaris and Staphylococcus aureus. All strains were collected from Biochemical division, Department of applied science, University of Technology. The identity of all the strains was confirmed. A bacterial suspension was prepared and added to the sterilized medium before solidification. The media with bacteria was poured into sterilized Petri dishes under aseptic condition. Different weights of the extractants (alcoholic, mthanolic, acetonitrilic, and hexanic, $0.02 \mathrm{M}$ ) in N,Ndimethylformamide (DMF) solvent were placed on the surface of the culture and incubated at $37^{\circ} \mathrm{C}$ for 24 hours. After incubation the average of inhibition zones was recorded [7-8].

\section{Determination of Free Serum Testosterone:}

The level of free serum testosterone was measured according to Enzyme-linked immunosorbant assay [9].

\section{Animals}

Healthy, adult 20 male mice weighing 25-30g, aged 2-3 months were used in this study. The animals had free access to a standard commercial diet and water; they were kept in 
rooms maintained at $25-27^{\circ} \mathrm{C}$. The animals were divided randomly into different groups; each group consisted of six male mice.

First Step: Control group 2 male mice orally treated with distilled water $(2 \mathrm{ml} / \mathrm{kg})$ three times per week for 45 days.

Second Step: Group 2 (3 male mice) orally treated with 70\% alcoholic extract $20 \mathrm{mg} / \mathrm{kg}$ body weight three times per week for 45 days.

Third Step : Group 3 (3 male mice) orally treated with methanolic extract $20 \mathrm{mg} / \mathrm{kg}$ body weight three times per week for 45 days.

Forth Step: Group 4 (3 male mice) orally treated with acetonitrilic extract $20 \mathrm{mg} / \mathrm{kg}$ body weight three times per week for 45 days.

Fifth Step: Group 5 (3 male mice) orally treated with hexanic extract $20 \mathrm{mg} / \mathrm{kg}$ body weight three times per week for 45 days.

Sixth Step: Group 6 (3 male mice) orally treated with Bulgarians Tribulus terrestris extracts $50 \mathrm{mg} / \mathrm{kg}$ body weight three times per week for 45 days.

Seventh Step: Group 7 (3 male mice) orally treated with methyltestosterone $3 \mathrm{mg} / \mathrm{kg}$ body weight three times per week for 45 days. Genotoxicity assay, the chromosome preparation of germ cells of mouse was done according to air drying method for meiotic preparation[10].

\section{Results and Discussion:}

Thin Layer Chromatography . Table (2) shows the TLC analysis results, and indicates the $\mathrm{R}_{\mathrm{f}}$ value for the Acetonitrili extractant.

\begin{tabular}{lllll}
\hline Extractants & Mobile phase & $R_{\mathrm{f}}$ value & Name & Structures \\
Acetonitrilic Acetonitrile:water(80:20) $9 \mathrm{~cm}$ & Furostanol
\end{tabular}

The determination of the MIC (Minimum inhibition concentration) by means of the agar diffusion assay Table (2) showed that 4 plant extracts tested exhibited an antimicrobial effect against Gram positive bacteria, Staphylococcus aureus and Gram negative, Klebsiella, Proteus vulgasis, Pseudomonas and E. coli. The antibacterial activities of the plant extracts were evaluated by measuring the inhibition zone observed around the tested materials. 
Table (2): The MIC values in $\mathrm{mg} / \mathrm{mL}$ of T. terrestris extracts in Agar diffusion assay.

\begin{tabular}{|c|c|c|c|c|c|}
\hline \multirow[t]{2}{*}{ Extractants } & \multicolumn{5}{|c|}{ Bactreia } \\
\hline & $\begin{array}{l}\text { Staphylococcus } \\
\text { aureus }(\mathrm{G}+\mathrm{ve})\end{array}$ & $\begin{array}{l}\text { Escherichia } \\
\text { coli (G -ve) }\end{array}$ & $\begin{array}{c}\text { Proteus } \\
\text { vulgasis (G -ve) }\end{array}$ & $\begin{array}{c}\text { Pseudomonas } \\
\text { aerugiuosa (G - } \\
\text { ve) }\end{array}$ & Klebsiella(G-ve) \\
\hline 70\%Ethanolic & 3 & 3 & 2 & 2 & 3 \\
\hline Methanolic & 3 & 3 & 3 & 2 & 3 \\
\hline Acetonitrilic & 2 & 2 & 2 & 2 & 2 \\
\hline Hexanic & 5 & 5 & 6 & 5 & 7 \\
\hline
\end{tabular}

The $70 \%$ ethanolic and methanolic extract of $T$. terrestris has activity against Staphylococcus aurues, Klebsiella and Escherichia coli, but Hexanic extract of T. terrestris has less detectable anti-bacterial activity, against any all kinds of bacteria. Table (3).

Table (3): Antibacterial activity of T. terrestris extracts against bacteria in Agar diffusion assay compared with Gentamycin .

Extractants

\begin{tabular}{lccccc} 
& $\begin{array}{c}\text { Staphylococcus } \\
\text { aureus(G +ve) }\end{array}$ & $\begin{array}{c}\text { Escherichia } \\
\text { coli (G -ve) }\end{array}$ & $\begin{array}{c}\text { Proteus } \\
\text { vulgasis(G -ve) }\end{array}$ & $\begin{array}{c}\text { Pseudomonas } \\
\text { aerugiuosa }(\mathrm{G}-\end{array}$ & $\begin{array}{c}\text { Klebsiella }(\mathrm{G}- \\
\text { ve) }\end{array}$ \\
70\%Ethanolic & 24.2 & 20 & 21 & 20 & 22.5 \\
Methanolic & 23.2 & 17.3 & 20.7 & 20.5 & 21.5 \\
Acetonitrilic & 24.8 & 15.7 & 17.5 & 20.5 & 19.5 \\
Hexanic & 13 & 11.5 & 13.3 & 11.5 & 9.5 \\
Gentamycin & 15 & 15 & 17 & 18 & 16 \\
\hline
\end{tabular}

\section{Biological activity on male mice:}

T. terrestris extract improves the body's ability to build muscle mass and strength by promoting the production luteinizing hormone, thereby stimulating the secretion of testosterones, resulting in the development of male-like characters (i.e. strong muscles and strength) with increase in sex drive, as well as production of red cells, contributing to improvement in blood circulation and good oxygen transport. [11-16].

\begin{tabular}{lc} 
Table (4): Free serum testosterone level in male mice $(\mathrm{ng} / \mathrm{ml})$ \\
\hline Extractants & Free serum testosterone level in male mice $(\mathrm{ng} / \mathrm{ml})$ \\
Control & 9.1 \\
$70 \%$ Ethanolic & 21.1 \\
Methanolic & 24.2 \\
Acetonitrilic & 23.9 \\
Hexanic & 10.7 \\
\hline
\end{tabular}

The spontaneous frequency of chromosomal aberration (CAs) in mous germ cells was $(0.18$ $\pm 0.06)$ which represents a control table (4). The results of this experiment indicates that $(0.2,0.4,0.8) \mathrm{mg} / \mathrm{mL}$ of methyltestosterone can increase CAs frequencies (Ring chromosome, chromosome break and chromatid break) more than methanolic, ethanolic extracts and also tribestane which reached to $(0.36,0.42,0.44)$. These results were 
significantly different $(\mathrm{P}<0.05)$ from the control. The chromosomal aberration induction by methyltestosterone is not fully understood. Suggested that the inhibition of chromosomal protein synthesis might cause a weakening of chromosomal backbone and subsequent chromosomal aberration [17] or may be related to the testicular damage as manifested by reduced testicular volume, elevated FSH and LH protein[18]. Several chemotherapeutic such as fludarabin, cyclophosphamide can cause this damage [19]. The extracts of Iraqi Tribulus terrestris after seven days of treatment by alcoholic, extract, water extract non significant decrease in CAs compared with control, these extracts contain many compounds which may increase the activity of the detoxification enzymes such as superoxide dismutase andglutathione-S-transferase that scavenging free radicals from the cells[20].

Table (5): Effects of Tribulus terrestris extracts, Tribestan \& Methyl Testosterone on chromosomal aberrations in germ cells of mice.

\begin{tabular}{|c|c|c|c|c|}
\hline & Total $($ mean \pm SE) & $\begin{array}{c}\text { Ring } \\
\text { chromosome } \\
(\text { mean } \pm \text { SE) }\end{array}$ & $\begin{array}{c}\text { Chromosome } \\
\text { break(mean } \\
\quad \pm \mathrm{SE})\end{array}$ & $\begin{array}{c}\text { Chromatid } \\
\text { break } \\
(\text { mean } \pm \text { SE) }\end{array}$ \\
\hline Control & $0.18 \pm 0.06$ & $0.02 \pm 0.005$ & $0.08 \pm 0.06$ & $0.08 \pm 0.04$ \\
\hline Methanolic extr. & $0.16 \pm 0.02$ & $0.05 \pm 0.01$ & $0.04 \pm 0.01$ & $0.07 \pm \mathbf{0 . 0 1}$ \\
\hline $0.2 \mathrm{mg} / \mathrm{mL}$ & $0.23 \pm 0.04$ & $0.04 \pm 0.01$ & $0.08 \pm 0.01$ & $0.11 \pm 0.02$ \\
\hline $0.4 \mathrm{mg} / \mathrm{mL}$ & $0.26 \pm 0.05$ & $0.05 \pm 0.05$ & $0.08 \pm 0.05$ & $0.13 \pm 0.05$ \\
\hline \multicolumn{5}{|l|}{$0.8 \mathrm{mg} / \mathrm{mL}$} \\
\hline $70 \%$ Ethanol.ext & $0.21 \pm 0.04$ & $0.18 \pm 0.01$ & $0.06 \pm 0.03$ & $0.07 \pm 0.02$ \\
\hline $0.2 \mathrm{mg} / \mathrm{mL}$ & $0.27 \pm 0.08$ & $0.11 \pm \mathbf{0 . 0 3}$ & $0.12 \pm 0.02$ & $0.04 \pm 0.02$ \\
\hline $0.4 \mathrm{mg} / \mathrm{mL}$ & $0.15 \pm 0.03$ & $0.00 \pm 0.00$ & $0.15 \pm 0.01$ & $0.07 \pm 0.01$ \\
\hline \multicolumn{5}{|l|}{$0.8 \mathrm{mg} / \mathrm{mL}$} \\
\hline Tribestan & $0.28 \pm 0.19$ & $0.08 \pm 0.01$ & $0.08 \pm 0.05$ & $0.12 \pm 0.01$ \\
\hline $0.2 \mathrm{mg} / \mathrm{mL}$ & $0.38 \pm 0.13$ & $0.050 \pm 0.01$ & $0.12 \pm 0.05$ & $0.21 \pm 0.07$ \\
\hline $0.4 \mathrm{mg} / \mathrm{mL}$ & $0.15 \pm 0.07$ & $0.05 \pm 0.01$ & $0.04 \pm 0.01$ & $0.06 \pm 0.03$ \\
\hline \multicolumn{5}{|l|}{$0.8 \mathrm{mg} / \mathrm{mL}$} \\
\hline Methyltestosterone & $0.36 \pm 0.06$ & $0.12 \pm 0.03$ & $0.08 \pm 0.02$ & $0.16 \pm 0.01$ \\
\hline $0.2 \mathrm{mg} / \mathrm{mL}$ & $0.42 \pm 0.08$ & $0.12 \pm 0.02$ & $0.12 \pm 0.02$ & $0.18 \pm 0.04$ \\
\hline $\begin{array}{l}\mathrm{mg} / \mathrm{mL} \\
0.8 \mathrm{mg} / \mathrm{mL}\end{array}$ & $0.44 \pm 0.07$ & $0.04 \pm 0.01$ & $0.21 \pm 0.01$ & $0.19 \pm 0.05$ \\
\hline
\end{tabular}

\section{References}

1. Mothana, R. A.; Lindequist, U.; (2005). Antimicrobial activity of some medicinal plants of the island Soqotra. J. Ethnopharmacol., 96(1-2):177-181.

2. Abeywickrama, K.; Bean G. A.; (1991). Toxigenic Aspergillus flavus and aflatoxins in Sri Lankan medicinal plant material. Mycopa-thologia., 113: 187-190.

3. Gauthaman, K.; Ganesan, A. P.; and Prasad, R. N.; (2003). "Sexual effects of puncturevine (Tribulus terrestris) extract (protodioscin): an evaluation using a rat model". Journal of Alternative and Complementary Medicine., 9 (2): 257-265. 
4. Majeed, S. H.; Mahmood, M. J.; (1988). Herbs and Medicinal Plants in Iraq between Traditional Medicine and Scientific Research. 1st Ed. Baghdad: Dar Al-Thaowra for Publishing., p. 40. (in Arabic).

5. Saad Aldein, S. M.; (1986). Medicinal Herbs. 1st Ed. Baghdad: Dar Al-Shoun AlThaqafia Al-Aama for Publishing., p. 70. (in Arabic).

6. Cowan, M. M.; (1999). Plant products as antimicrobial agents. Clin. Microbiol. Rev. 12(4): 564-582.

7. Kandil, O.; Radwan N. M.; Hassan, A. B.; Amer A. M.; El-Banna H. A.; (1994). Extracts and fractions of Thymus capitatus exhibit antimicrobial activities. $J$ Ethnopharmacol., 44(1):19-24.

8. McCann D, Kirkish L: Evaluation of Free Testosterone in serum. J Clin Immunoassay. 1985; 8: 234-236.

9. Atlas M.R. Alfres E., Brown and Lawrence C. parks "Laboratory Manual Experimental Microbiology" Mosby- Year Book, Inc.;(1995).

10. Evans, E., Breckon, G., and Ford, C. (1964) $\mathrm{n}$ air drying method for meiotic preparation from mammalian testes. Cytogenetics 3: 284-294.

11. Brown AG, Vukovich MD, Martini ER, Kohut LM, Frank WD, Jackson DA, et al . Endocrine and lipid responses to chronic androstenediol-herbal supplementation in 30 to 58 year old men. J Am Coll Nutr 2002;20:520-528.

12. Arsyad KM. Effect of protodioscin on the quality and quantity of sperms from males with moderate idiopathic oligozoospermia. Medica 1996;22:614-618.

13. Tyutyulkova, N.; Taskov, M.; and Manolova, B.; (1988). MBI: Medicobiologic Information., 6: 27-30.

14. Dimova, P.; ,Matev, T.; Taskov, M.; (1988). MBI: Medicobiologic Information., $6: 1$ :1-10.

15. Sheitanov, M.; Khristov, T.; Taskov, M.; (1988). MBI: Medicobiologic Information., 1: 24-26.

16. Taskov, M.; Milanov, S.; Maleeva, A.; (1988). MBI: Medicobiologic Information., 1: 24-26.

17. Castoldi, G.; Scapoli, P.; and Spanedda, R. (1969). Chromosomes and chloramphenicol. Arch. Ital. Patol. Clin. Tumori, 12:117-141.

18. Al-Neimy, E.H. (2007). Biological effects of Capparis spinosa and Rumex acetosella extracts on animal and human normal and tumor cells. Ph.D. thesis, college of science, Al-Nahrain University.

19. Chatterjee, R.; Haines, G.A.; Perera, D. M.; Goldston, A.; and Morris, L. D. (200). Testicular and sperm DNA damage after treatment with fludarabin for chronic lymphocytic leukemia Hum. Reprod., 15: 762-766.

20. Wang, Z. y.; Chen, S. J.; Zhon, Z. C.; Athar, M.; Khan, W. A.; Bickers, D. R.; and Muthtar, H. (1989). Antimutagenic activity of green tea polyphenols. Mut. Res., 223: 273-285. 